\title{
The Beijing Perspective: the Political and Diplomatic Context for Taiwan and the World Health Assembly
}

\author{
Kerry Brown \\ Professor of Chinese Studies and Director, Lau China Institute, King's \\ College, London, UK \\ Kerry.brown@kcl.ac.uk
}

\begin{abstract}
Xi Jinping's People's Republic of China is keen to express its grand strategic ambitions - the delivery of centennial goals by 2021 and 2049. This marks the end in which China seeks to keep a low profile. With notions like the 'China Dream', the Belt and Road Initiative, and a raft of other expressions and moves, $\mathrm{Xi}$ and his fellow leaders have shown that they want a more proactive foreign policy. In this ambitious, historically driven and more nationalistic strategic approach, the issue of Taiwan remains central. There has been more attempt to make some kind of framework for reunification on the part of Beijing accepted both internationally, and in Taipei. Taiwan's space has been restricted, and a number of moves have placed pressure on the Tsai presidency, from trying to gain diplomatic allies currently linked to Taiwan, to refusing Taiwan space on the World Health Assembly and other bodies.
\end{abstract}

\section{Keywords}

Xi Jinping - Taiwan - China - Tsai Ing-wen - World Health Assembly

Taiwan's efforts to receive status and validation in the international community have focused in recent years at endeavouring to become members of bodies like the International Civil Aviation Authority (ICAA) and the World Health 
Assembly (WHA). While the former has, so far, largely failed, the latter met with some success with Taiwan, after a decade of lobbying, being granted observer status in 2009. This was revoked in 2018 after intense pressure from Beijing. The question is how to interpret Beijing's change of position in now preventing Taiwan's involvement in a body like the WHA (Guilloux, 2009; Lindemann, 2014). What does this mean for cross-Strait relations from the perspective of the People's Republic of China (PRC)?

What is clear is that this issue is symptomatic of the way that, under the leadership of Xi Jinping, the PRC has become even more assertive and dogmatic in its stance on any form of recognition granted by third parties to Taiwan. Never before has Taiwan seemed so isolated and so much like an irregular state - an entity with all the standard trappings of a sovereign nation, but with fewer and fewer, in their discourse at least, willing to grant it this status. Under $\mathrm{Xi}$, the pact that held in the latter era of his predecessor Hu Jintao up to 2012 to not compete with each other to gain diplomatic partners has broken down. Despite the bold move of Xi meeting the then-president of Taiwan, Ma Yingjeou, in 2015 in Singapore, Beijing's position hardened once a new government under the Democratic Progressive Party (DPP) in Taiwan came to power the following year. Its efforts have largely been in restraining, pressurising, and controlling Taiwan, with the WHA case as among the most high-profile and representative. As a press release in May 2018 from the official PRC news agency, Xinhua, curtly put it, when discussion of Taiwan's continuation of observer status was removed from the conference's provisional agenda:

The decision safeguarded the dignity of the relevant resolutions of the UN General Assembly and the WHA, which fully proved that the oneChina principle is the consensus of the international community and corresponds with the trend of the times.... I I would like to reiterate again that the Chinese government will properly handle the issue of Taiwan's participation in the activities of international organizations in accordance with the one-China principle,' Lu Kang (PRC Ministry of Foreign Affairs spokesperson) said. (Xiang Bo, 2018)

Every decision related to Taiwan made by Beijing, no matter how big or small, occurs in a particular policy context. This is the result of over six decades of evolving discussion and debate within Beijing, and as often as not relates to domestic issues and the PRC's self-identity as it does to Taiwan or the 
international situation. Under Mao Zedong from 1949, the approach after initial bellicosity settled down into an acceptance of the status quo, with the caveat that at some point in the future the issue of reunification on Beijing's terms would need to be addressed. As the price of rapprochement in the 1970s, the US under President Richard Nixon agreed on a form of words acknowledging a 'One China' principle which appeared in the 1972 Shanghai Communique. The impact of this policy is still with us today. The 'One China' principle has been the object of torturous definition and analysis, with no real consensus about the implications of its meaning to the present period. Different countries have subtly different interpretations, with the US, Australia, and the UK recognising there is only one China, and that the PRC is that China, but making clear that the issue of Taiwan has to be resolved by peaceful and consensual means (with the possibility that it could just become an entity in its own right in the currently unlikely event that everyone agrees to this). What is clear is that any country that wants to have diplomatic relations with the PRC has to at least pay lip service to the principle, and work out their own approach to it.

However, for Beijing, Taipei, and others, the principle has created in the four decades since the 1970s a wide space that can accommodate different actions and flexible approaches, guided by pragmatism. Under Deng Xiaoping as socalled paramount leader of the PRC in the 1980s and 1990s, the onus for national policy was on economic growth and rebuilding the country's military and diplomatic capacity as quickly as possible. In view of this, Taiwan became from the late 1980 s into the 1990 s an investment partner, and a more benign approach emerged - testified by Deng's public position that for an issue as complex as this it was best to let the future generations work something out. The main thing was to adhere to a holding position where no drastic concessions were made, and certain boundaries observed.

Those boundaries are best manifested in the attempts, under Jiang Zemin (president from 1989 until 2003) and then Hu Jintao (2003 to 2013), to articulate a key set of parameters for how cross-Strait relations were to be conducted, and where political red lines were. In January 1995, Jiang put forward an eightpoint proposal. This supported economic, cultural, and people-to-people exchanges, but resolutely opposed any moves to independence (Jiang, 1995). These broad lines were reiterated in 2008 by Hu Jintao in a four-point declaration made to Lien Chan, honorary chair of the Nationalist Party (Kuomintang, кмт) at the time. These were 'building mutual trust, laying aside disputes, seeking consensus and shelving differences, and creating a win-win situation' (Hu, 2008). This was amplified in a report on New Year's Day 2009, including six points for the management of cross-Strait issues: '1) firm adherence to the 
"one China" principle; 2) strengthening commercial ties, including negotiating an economic cooperation agreement; 3) promoting personnel exchanges; 4) stressing common cultural links between the two sides; 5) allowing Taiwan's "reasonable" participation in global organizations and 6) negotiating a peace agreement' (Hsiao, 2009). The fifth, of course, is highly germane to the specific issue discussed in this paper and in effect mandated Taiwan's admission to observer status of the WHA.

Taiwan was not a passive recipient of these announcements from Beijing. It too developed a series of policy positions in order to fulfil its own strategic objectives and, more broadly, create a pragmatic framework within which it would be able to work with Beijing, developing its economic, political, and diplomatic needs. The '1992 Consensus' was perhaps the most prominent, a position agreed in Hong Kong between both sides, in which both recognised that there was 'one China', but chose to interpret what this 'one China' meant in different ways. The '1992 Consensus' has been the subject of fierce controversy and debate ever since, with many attempts to simply scrap it made over the years, particularly by the DPP. Under the presidency of Tsai Ing-wen it has become a particular bone of contention, with Beijing almost demanding its affirmation, and the government of Taiwan seeking new forms of language and a new settlement. For instance, Tsai did not mention the consensus during her election campaign in 2016. After strong words from Xi Jinping in a new year's message in 2019, she effectively repudiated the policy, saying that its meaning was unclear and unhelpful (Tsai, 2019).

Leaders like Ma Ying-jeou did set out corresponding principles for crossStrait relations, similar in their programmatic and boundary-setting nature to those issued by Jiang and $\mathrm{Hu}$. Interestingly, while the Beijing language is framed in a mixture of positive and negative forms, for Ma the most important utterance was mostly of the latter variety - the 'three noes', set out before his election in 2008. These were 'no unification, no independence and no use of force' (Cossa, 2008).

The issue that has had the most significant impact on these policy positions in the last three decades is the introduction since 1996 of full universal franchise, free, multiparty democratic elections in Taiwan. The seismic importance of this event in shaping what Taiwan is and its impact on Taiwanese identity cannot be overstated. Taiwan in many ways is a different entity and a different place pre- and post-1996. Arguably, the Beijing position has never fully recognised, or been willing to recognise, this existential change. In practical terms, before 1996 Beijing had a unitary partner: the Republic of China (ROC) under continuous кмт rule, towards which it was able to direct pressure. This supplied a 'like with like' model, with two parties largely having a monopoly on 
power and, despite their very deep differences, a common understanding of history and of the notion of a 'greater China' which needed to be reunified eventually. After 1996, with opposition parties, one of which (the D PP) was successfully elected as the government in 2000 and 2016 , delivery of the PRC's strategic objective of reunification became more complicated. Its attempts to influence the situation on the island often showed a failure, or unwillingness, to acknowledge the scale of the changes. Heavy-handed use of military exercises close to Taiwan during the first election in 1996 only seemed to result in an even larger victory for the Lee Teng-hui presidency. Under Hu, the effort was more to simply keep silent during elections. Xi's meeting with Ma Ying-jeou in 2015 can be interpreted as a further subliminal attempt by Beijing to try to persuade the Taiwanese electorate to stick with a Км T administration in order to continue enjoying good economic links with the mainland as it occurred just before an election the following year. That was unsuccessful, with the DPP being returned to power comfortably only a few months later.

Beijing's lack of real understanding (or perhaps willing misunderstanding of a situation that did not suit it and therefore chose largely to ignore) of democratic systems and how they work from 1996 had a big impact on the frameworks outlined above by Jiang and Hu to 'manage' cross-Strait issues. This was because, at heart, the intention underlying these was an unchanged and very simple one - to have Taiwan reunify with the PRC at some point in the future. That brute statement of reality underpins all of the softer words and inducements that have been issued. Just as Beijing angrily denounces foreign governments for engaging with it economically in order to see political change manifest itself at some point and get democracy introduced, so it too can be accused of the same broad approach with Taiwan, though in reverse- to engage with an ulterior motive: political reunification in some shape or form. Allowing Taiwan a little leeway in terms of joining, in the softest way possible, an organisation like WHA as an observer can be seen in this context - granting of a favour with the expectation that Taiwan would reciprocate by being more positive and amenable to Beijing's unchanged reunification ambition. The Xi era marks the end of this tactic and the beginning of a harder approach.

\section{The Xi Era: Nationalism Redux}

Within this context, the particular nature, tone, and macro-strategic objectives of the Xi presidency since 2013 need to be located. The overall commitment to the 'One China' policy and political unification remains, as stated in the previous section, unchanged. The changes that have occurred manifest themselves 
in tone and approach. This derives from the condition in which Xi's PRC finds itself than to any fundamental changes in Taiwan, or in cross-Strait relations generally. The most striking aspect of the Xi strategy, which the case of the WHA illustrates well, is a categorical assertion of power. As Xi's new year's statement in 2019 made clear, Beijing feels that it controls the terms of the debate and has moved to simply close down Taiwan's international space. And while the US, Europe, and others see this as symptomatic of a PRC which is increasingly assertive and dominating in the Asian region, and willing to use its economy almost as a toll of coercion to enforce its will, in terms of realpolitik Xi's approach is working, causing any attempts by Taiwan to express its identity and have this validated to be stifled, and even impacting on the way that people on the island are willing to speak about their situation. In addition, part of Xi's foreign policy posture can be seen as a necessary response to the economic and political uncertainty in the outside world from the global financial crisis of 2008 onwards, where Beijing has become more aware of the need to be self-reliant and have relations with the wider world increasingly on its own terms.

It is also clear that under $\mathrm{Xi}$, nationalism is a strengthening pillar of legitimacy for the Communist Party, whereas up to the late 2ooos the main source of its right to a monopoly on power was economic delivery; Hu Jintao, during his speech at the 17th Party Congress in October 2007, made clear that economic performance was the most important duty of the Chinese government. As gross domestic product growth has fallen to a more modest $6-6.5$ percent from 2013, focus has shifted to more complex legitimising measures under $\mathrm{Xi}$. In 2013, the 'China Dream' language emerged, with the promise to make the country one where people's living standards were high, their international status enhanced, and the PRC seen as a major global power. Language around 'national renaissance' and rejuvenation, and fulfilment of historic missions increased. Xi and his politburo colleagues visited the Museum of Revolutionary History in Beijing in early 2013 in order to reinforce the notion of the oneparty system being a form of salvation for the PRC, and the main strategic asset in delivering a great nation with stability and sustainability. The whole political programme of the $\mathrm{Xi}$ era can be summarised in one statement: to make one-party rule in China sustainable. Nationalism feeds into this mission (Weatherley \& Zhang, 2017).

On top of this is the emergence of grand narratives within China since 2012 when Xi became party secretary. The power of stories that appeal to people's emotions and offer a source for unity and consensus in a country often riven by social, regional, and other fractures, despite its placidly unified appearance on the surface, has become increasingly evident. This is, of course, a phenomenon 
that is by no means unique to the PRC - Trump's 'Make America Great Again' and the UK with its Brexit adventures from 2016 are good examples of stories involving national identity and trying to reclaim a previous golden age. But the power of the current narratives promoted by $\mathrm{Xi}$ and leaders around him has proved potent. In essence, since the 199os a story of national humiliation in the pre-1949 era, at the hands of colonisers such as Great Britain in the late Qing era, or aggressors such as the Japanese during the 1937-1945 war, has been promoted through education, media, and propaganda in the Chinese popular consciousness. It has shaped the language by which leaders, and much of the public, think about their identity and the own pasts, and the sort of future they want (Callahan, 2008; Hall, 2015; Z. Wang, 2014).

Under Xi this phenomenon has simply intensified. A view of history with a teleological purpose, something largely derived from Marxism-Leninism with its dialectic materialist view of historic development, has been combined with the language reaching back to the Qing era of China's project of modernity being concerned with achieving a 'strong, rich country' (Deleury \& Schell, 2013). In the Xi narrative, the Mao era of experimentation and socialist reconstruction from 1949 to 1976 created a body of knowledge about the unique conditions in the PRC and the precise form of modernity that might be applicable to these. Reform and opening up since 1978 has simply continued trying to pursue the same objective-creation of a powerful, strong, independent country-but with different tactics (economic rebuilding rather than cleansing of society through class struggle). Unlike in many of the external historiographies, where PRC history before and after 1978 are seen as marking two very different phases, for Xi they are simply part of the same continuum. Their fundamental mission (a word he used over 6o times in his epic address to the 19th Party Congress in October 2017) is a nationalistic one (Xi, 2017).

Under Xi, the historic narrative has even been given a particular time frame with the two centennial goals: one for 2021 celebrating the hundredth anniversary of the foundation of the Chinese Communist Party (CCP) and one for 2049 marking the centenary of the PRC itself. These shape a story about the future to which the CCP now speaks, and a rubric which directs almost all policy and international relations. The notion is a very simple one: history has, under the Communists, a moral narrative. The time of rejuvenation and achievement of modernity with Chinese characteristics, and on the PRC's terms, is imminent. Never again, Xi and his colleagues are saying, under the unified leadership of the Party will the country be returned to the lamentable, wretched condition of victimisation and humiliation it experienced in the past. With the associated grand narratives of the 'Belt and the Road Initiative', Xi's P RC is seeking validation and status from the world as a great power restored to its central global 
position, one it believed it occupied in the pre-modern era. And while the vast majority of Chinese do not believe in sinified Marxism-Leninism, nor in the intricacies of Xi Jinping's thought as spelled out at the aforementioned 2017 congress and placed in the Constitution, they are certainly emotionally recruited by language about a great powerful nation, and one which they will see erected in their own lives before their eyes, rather than some abstract possibility projected far into the future (Brown, 2018).

\section{Time to Move on: PRC Nationalism and the Issue of Taiwan}

Unlike Jiang and $\mathrm{Hu}$, $\mathrm{Xi} \mathrm{Jinping} \mathrm{has} \mathrm{not} \mathrm{produced} \mathrm{a} \mathrm{list} \mathrm{of} \mathrm{key} \mathrm{points} \mathrm{or} \mathrm{propos-}$ als about the management of Taiwan but a set of assertions or almost command-like utterances that are in keeping with the more assertive foreign policy whose genesis dates from the early period of his time in power in 2013 (Xi, 2019). The notion of the PRC working to an agenda that suits the outside world but not itself is over. Many have commented on this more forceful nature of Chinese foreign policy under Xi. Speaking at the Central Conference on Work Relating to Foreign Affairs in Beijing in 2014, Xi requested that China pursue a more comprehensive, strategic, and outward-looking foreign policy stance. According to the official Xinhua news agency summary of the speech carried on the Ministry of Foreign Affairs (MOFA) website, Xi:

stressed that China should develop a distinctive diplomatic approach befitting its role of a major country. We should, on the basis of summing up our past practice and experience, enrich and further develop principles guiding our diplomatic work, and conduct diplomacy with a salient Chinese feature and a Chinese vision. (MOFA, PRC, 2014)

The ethos of the famous Deng Xiaoping ' 24 character statement' of foreign affairs - roughly translated as 'Observe calmly; secure our position; cope with affairs calmly; hide our capacities and bide our time; be good at maintaining a low profile; and never claim leadership' - that emerged after the 1989 Tiananmen Square incident is being superseded by something more ambitious, accompanied by a tone and attitude to foreign affairs that is seen as more commensurate to the world's second largest economy. Meekness and humility are consigned to the past. Under $\mathrm{Xi}$, China can walk tall and stand proud Such a posture has gained it a reputation as not so much a hard power, or soft power actor, but a sharp power one. Taiwan has been at the forefront of this new attitude, as the pushiness and assertiveness over the wHA issue makes 
abundantly clear. For Beijing it figures as a key testing ground, one that it needs to prove able to control and deliver on its agenda. Even the wHA figures in that battlefield.

However, part of the $\mathrm{Xi}$ approach is also down to the new unfolding dynamics that come from the Party now locating its legitimacy in nationalism and the delivery of this all-important but often vague notion of a great, strong country, and part from an awareness that the international situation, from the 2008 global economic crisis onwards, is becoming more potentially troublesome to the PRC. Reunification and the need to ensure complete unity of purpose domestically and a strong line to the outside world is part of this. Taiwan is at the head of Beijing's priorities, an issue over which it has made clear it will not allow itself to be manipulated. This hard stance is seen most clearly in PRC policy on Hong Kong where, two decades on from the reversion to PRC sovereignty, it is being treated increasingly within a rubric from Beijing where 'one country' gets complete priority over 'two systems'. Beijing disregards the very negative message that the closing down of political space in Hong Kong in recent years, and particularly since the Occupy Central protests of 2014, has created in Taiwan. It is impatient, and increasingly emboldened, thinking that the era of working within the pre-created frameworks of others over these issues is in the past. Xi's comments and actions on Taiwan therefore have been demonstrated by action and attitude rather than anything spelled out in new policies.

The key incident heralding this was the meeting with a former vice president of Taiwan, Vincent Siew, on 6 October 2013 in China, when Xi was recorded as stating that:

the longstanding political division between the two sides will have to be eventually resolved step-by-step as it should not be passed on generation after generation.... We have reiterated that we are willing to engage in reciprocal negotiations on bilateral political issues with Taiwan under the 'One China' framework. (C. Wang, 2013)

The meaning of the statement 'not be passed on generation after generation' became clearer when rumours of the first ever person-to-person meeting between a leader of the PRC and that of Taiwan became reality in November 2015. Ma Ying-jeou's historic summit with Xi in Singapore marked the high point of a moment of optimism, and one where it seemed, at least on the surface, that $\mathrm{Xi}$ was able to deliver even higher forms of flexibility and pragmatism on the management of the Taiwan issue than his predecessors. That Xi had the domestic political capital and authority to agree and then carry through with such a meeting showed how much he controlled domestic politics. But in 2019 
we can see how it also marked the start of a sharper attitude from the PRC to cross-Strait issues. Within a few months Ma was no longer president, and the DPP, historically much tougher on the issue of relations with the PRC, and with a greater number of members supporting outright declarations of independence, came to power under President Tsai Ing-wen. The détente, such as it was, came to a halt, and the PRC's version of the sunshine policy, involving economic and other forms of cultural and social inducements, ran into a major eclipse. Maybe this was always likely, but the suddenness and completeness of the move has been striking.

\section{The Taiwan-P RC Nexus: Structural Impediments}

The whole WHA argument in 2018 occurs as part of this larger story. Added to that has been the particular increase in nationalist tone and approach under $\mathrm{Xi}$. All of these have accentuated the following structural issues, making Taiwan-PRC relations even more difficult than they had been under Jiang and $\mathrm{Hu}$ in an earlier era.

First, there is the issue of there being no fresh thinking about the fundamental policy of the PRC towards Taiwan, but more a simple change in tone to a stronger assertion of what has already and consistently been demanded by Beijing: a track to reunification and a resolution of the issue of Taiwan within this rubric. For all the bold expending of political capital by $\mathrm{Xi}$ in meeting $\mathrm{Ma}$ Ying-jeou, in terms of underlying policy approach the 'One China' policy from Beijing remains rigidly unchanged, with perhaps even less space for flexibility than in the past. With its nationalist discourse of rejuvenation and restoring China to a unified, strong, powerful position, Taiwan is now firmly cemented in that narrative. There is an inner logic which says that this historic mission, the one so crucial to the legitimacy of the Xi leadership, will be incomplete until there is a resolution of the Taiwan issue. It lies at the heart of the various promises and plans that the Xi leadership have made, about a country which is restored to an historical unity, and one which can now say for the first time in modern history that it is integral, restored to absolute pure unity, and no longer scarred by the prior experience of humiliation and exploitation. Regardless of the many powerful arguments, some even emanating from within the PRC, such a historic narrative is largely incomplete, grossly oversimplified, or simply in parts fallacious. Taiwan island's history is at best highly complex, and relates in different ways over the modern era to different governments in the Ming, Qing, Republican, or PRC era. Yet so much effort has been put into cementing this story in place both by the Communist Party and its propaganda and 
ideological apparatus, it is hard to see how it can be diluted or removed without something approaching a crisis of faith $(\mathrm{Ge}, 2018)$.

This has been accentuated by the fact that the emotional appeal of nationalism has become so compelling in the PRC, and that delivery of a strong, powerful nation (and one therefore where Taiwan figures as a part) stands akin almost to a religion. The PRC government have painted themselves into a corner from which they cannot, and do not want to, reverse on this. Its main proposal for a model of reunification, the 'One Country, Two Systems' rubric, has, after two decades of use in Hong Kong, shown plenty of flaws. It is, in essence, an unattractive model to Taiwanese, a situation made all the more complicated by the fact that it has in any case only worked in a non-democratic context, and it is therefore wholly untested in one where democracy has taken root and is such a major part of the identity of the people of a particular place. On all these issues, the intellectual parameters within which the Xi leadership operate show no signs of fresh thinking or new ideas, nor of needing these because of Beijing's global clout. In essence, the policy approach remains as it has for the last few decades, with no desire to challenge or revise this domestically within the PRC. The strategic assumption is that Taiwan's current government needs to look after its people economically, and that as much of its trade and investment is wrapped up with the PRC, along with its ability to operate internationally, Beijing can now be increasingly coercive in the ways it uses these levers. The WHA issue, once more, is illustrative of this.

Beijing remains wedded to models and approaches to Taiwan that continue to show not so much a lack of appreciation for just how profoundly Taiwanese have changed since 1996 as they have developed as active participants in a democracy, but more a willing indifference to this. It is almost as though the current PRC leaders want to fit the island into a reality that exists to suit them and is heedless of the real and dramatic changes that have happened across the Strait. This is exacerbated by the fact that Beijing's attitude towards democracy generally has deteriorated in the last few decades as it has seen a series of crises perplex the US and the European Union, and elsewhere (Brazil, for instance). This means that it not only does not agree with the politics of Taipei, but often seems to have disdain for it. The stark fact remains that the Taiwanese political system has fundamentally impacted on not just systems and processes, but the fundamental identity of Taiwan's people. For all Beijing's nonchalant dismissal of this phenomenon of a radically changed sense of what it is to be Taiwanese now the island is a democracy as something manageable within a more generous, flexible 'One Country, Two System' model, it is hard to see how two such contrasting polities and conceptualisations of citizenship can cohabit together under any system that does not recognise that they are 
not only dissimilar but radically different. As Xi's statement in January 2019 referred to earlier made clear, the main tactic to try to overcome this is to take Taiwan by making emotional, rather than political (and therefore more rational), appeals. Either side of the Strait, says this narrative, people are of one blood, one ethnic inheritance, one cultural family. This, of course, pays little heed not only to the political changes that have happened and their impact on Taiwanese, but also to the diversity and the aborigine history of Taiwan. It is symptomatic of Beijing's general impatience with individualistic discourses and its historic commitment to more collectivist ones. This emotional tactic is underpinned by hard practical threat- that for decent economic development and prosperous lives, Taiwan needs to rely on the massive, fast-growing market of the PRC. This dual-track appeal is brutally simple, but coherent and effective in terms of the harshly realist way that the PRC under Xi sees the world. Attempts to express agency on Taiwan by actors there have been circumscribed by an almost diplomatic 'zero-tolerance' approach from Beijing; from attempting to stop Taiwan being named as a country entity on airlinebooking websites to resolutely insisting that even the slightest manifestation of Taiwanese independent identity is closed down, and that Taiwanese are aware that they operate in a space granted to them, on terms allowed them, by the PRC rather than from themselves.

The attempt to negatively influence Taiwan's economy is most easily seen by looking at the reduction of tourist flows from the PRC into Taiwan from 2016, and the enforcement of trade and investment restrictions over the same period (despite the fact that these improved from other sources). Unlike in the $\mathrm{Hu}$ era where there was some level of benign cooperation, under Xi the PRC has been vigorously trying to compete with Taiwan as an international trade actor, and reducing what limited technological dependency it has on the island through the 'Made in China 2025' campaign and other measures. Despite this, Taiwan still maintains a strategic advantage in terms of production of goods like superconductors. Parallel to this freezing of economic space has been a much more assertive move to take Taiwan's diplomatic allies and an end of the truce under Xi. Taiwan's allies numbered 21 when Tsai came to power in 2016. They became 17 by the time of writing in September 2018 (MOFA, ROC, 2019). This followed a freeze in the competition for allies between the PRC and Taiwan in the 20oos under Hu when Ma Ying-jeou came to power in 2008. The final part of this strategy of hardening and closing down Taiwan's international space has been the campaign to ensure that Taiwan does not have representation on the ICAA and WHA.

This tightening of Beijing's posture on Taiwan has been compounded by the impact of the Trump presidency since 2017, and the uncertainty that this has 
produced in Beijing and elsewhere. Trump's telephone call to Tsai Ing-wen in late 2016 before he was inaugurated sent shockwaves through the Beijing administration, waves which were intensified by the statements the new president made when he questioned the 'One China' policy and wondered why the US continued to stand by it. A visit by Xi to Trump's Mar-a-Lago resort in April 2017 seemed to bring relations back into a more orthodox pattern, but this was to prove only temporary. In 2018 Trump launched a preliminary trade war with the PRC, imposing tariffs on a range of its goods because of frustration over trade imbalances in China's favour and a frustration at what has been seen as China's lack of a sense of reciprocity in the way that it allows others access to its markets while enjoying largely unfettered access to theirs. That Trump has seen Taiwan as a point of vulnerability by which to antagonise and pressure Beijing is evidently as much a source of worry in Taipei as it is in Beijing. It has made cautiousness about the cross-Strait relationship even more intense. The bottom line is that at the moment $\mathrm{Xi}$ will not promote any larger policy changes or new initiatives in this area but maintain the current holding pattern, intensifying the assertive tone of diplomacy and letting that do the main work. Remorselessly stressing adherence to the 'One China' policy and the need for a framework, however loose, for reunification to be put in place, and seeking to deny Taiwan, partly as a response to the attention Trump has brought it, as much space and opportunity as possible. This has been supplemented by an attempt to influence opinion within Taiwan by stressing the emotional and economic importance of the links between the two, and their need to be reunited in achieving the historic mission, as Xi and his colleagues call it, of a rich, powerful, and strong China.

Invariably, in a case like Taiwan and the WHA, one sees PRC diplomacy at its sharpest. This is the result of two main influences. One is the rising sense of urgency as Xi's PRC comes to achieve its self-proclaimed moment of national rejuvenation from 2021 and the marking of the first centennial goal. This narrative of history has created its own momentum and logic and left little space for flexibility, fresh thinking, and compromise, particularly on an issue as emotionally and politically important to the PRC in this narrative as Taiwan's status. There is little appetite to take risks and try new approaches, because the stakes for the PRC have risen so high, and because, as cases like the WHA show, as far as Beijing sees the issue at the moment, its approach is working. 
It is hard to predict in this sort of environment, with so many variables, where the situation may be heading. At the moment, it seems the Xi leadership is operating as though it had a time frame by which it wants some kind of palatable resolution of what it itself regards as the Taiwan problem. Such a framework might be a soft, largely symbolic one where there are commitments to some kind of discussion of a long-term resolution of the issue-though these will inevitably hit the rock of the 'One China' principle and all the associated complexity that comes with it. In effect, the PRC is still insisting on a discussion where it has already decided the conclusion. It is easy to see why no Taiwanese administration would be able to embark on this sort of debate. The possibility of military action and force is low, but cannot be discountedespecially if the situation within Taiwan means the Xi leadership or its successors are forced to use such external adventurism to create consensus and support should they hit an unexpected economic or political crisis. Taiwan would then truly prove it is the tail that wags the dog, subjecting Beijing to a course of action against its best interests, but brought about by the forces of nationalism it has done so much to encourage in the last few years.

As ever, everything is dependent on political issues within the PRC itself. At the moment, the possibility of substantial reforms looks remote. But for all the tactical consolidation and centralisation of power under $\mathrm{Xi}$, there is an underlying game that is hard to properly divine at the moment: what does 'democracy with Chinese characteristics', something that has been promised in the next few decades, actually mean? It seems increasingly unlikely it will not be on the model and pattern used by others. But one thing is certain: there will need to be some kind of reforms as a middle class emerges in the PRC with greater economic and therefore political importance, and almost certainly a desire for more of a voice than it has at the moment. Taiwan will continue to be the frontline of exposure to evolving PRC power and development. The WHA experience in 2018 shows a commitment to a strongly realist framework by Beijing, where emotion, economic inducements, and isolating Taiwan internationally and attempting to create division within it are implemented, with willing disregard of the impact that democratisation has had on the island's identity. But as in the past, abrupt and unexpected changes might be afoot when least expected. We just have to hope these are positive ones, while preparing for negative ones and thinking through how these may be managed. Because of the importance of the region, and the significance of the PRC's role, Taiwan with its geopolitical importance is a matter in which everyone needs to be interested and engaged — not just those engaged with Taiwan studies. 


\section{Kerry Brown}

is Professor of Chinese Studies and Director of the Lau China Institute, King's College, London, and Associate Fellow on the Asia Pacific Programme at Chatham House, London. From 2012 to 2015 he was Professor of Chinese Politics and Director of the China Studies Centre at the University of Sydney. Prior to this, from 1998 to 2005, he served as a diplomat in the British Foreign and Commonwealth Office, and then from 2006 to 2012 Senior Fellow and then Head of the Asia Programme at Chatham House. He was Director of the Europe China Research and Advice Network funded by the European Union. He is the author of 20 books, the most recent of which are China's Dreams: The Culture of the Communist Party and the Secret Sources of its Power (Polity, Cambridge, 2018) and The Trouble with Taiwan: History, the United States and a Rising China (Zed Books, London, 2019).

\section{References}

Brown, Kerry (2018) China's Dream: The Culture of the Communist Party and its Secret Source of Power, Cambridge: Polity Press.

Callahan, William (2008) China: The Pessoptimist Nation, Oxford: Oxford University Press.

Cossa, Ralph (2008) 'Looking behind Ma's three noes', Taipei Times, 21 January. Retrieved 2 September 2018 from www.taipeitimes.com/News/editorials/archives/ 2008/01/21/2003398185.

Deleury, John and Schell, Orville (2013) Wealth and Power: China's Long March to the Twenty First Century, New York: Random House.

Ge, Zhaoguang (2018) What is China: Territory, Ethnicity, Culture and History, trans. HillMichael Gibbs. Cambridge, MA: Belknap Press.

Guilloux, Alain (2009) Taiwan, Humanitarianism, and Global Governance, London: Routledge.

Hall, Todd (2015) Emotional Diplomacy: Official Emotion on the International Stage, Ithaca, NY: Cornell University Press.

Hsiao, Russel (2009) 'Hu Jintao's “Six-Points" proposition to Taiwan', Jamestown Foundation, 12 January. Retrieved 2 September 2018 from https://jamestown.org/ program/hu-jintaos-six-points-proposition-to-taiwan/.

$\mathrm{Hu}$, Jintao (2008) 'Hu Jintao calls for mutual trust, consensus with Taiwan', Embassy of the PRC to the USA, 30 April. Retrieved 2 September 2018 from www.china-embassy .org/eng/zt/twwt/t448548.htm.

Jiang, Zemin (1995) 'Jiang Zemin's eight point proposal', China Radio International, 11 January. Retrieved 2 September 2018 from http://english.cri.cn/4426/2007/01/11/ 167@184028.htm. 
Lindemann, Björn Alexander (2014) Cross Strait Relations and International Organisations: Taiwan's Participation in IGO's in the Context of its Relationship with China, Berlin: Springer VS.

Ministry of Foreign Affairs, People's Republic of China (MOFA, PRC) (2014) 'The Central Conference on Work Relating to Foreign Affair was held in Beijing', 29 November. Retrieved 7 September 2018 from https://www.fmprc.gov.cn/mfa_eng/ zxxx_662805/t1215680.shtml.

Ministry of Foreign Affairs, Republic of China (MOFA, ROC) (2019) 'Diplomatic allies'. Retrieved 20 February 2019 from https://www.mofa.gov.tw/en/AlliesIndex.aspx?n= DF6F8F246o49F8D6\&sms=A76B723oADF29736.

Tsai, Ing-wen (2019) 'President Tsai issues statement on China's President Xi's “Message to Compatriots in Taiwan", Office of the President, Republic of China (Taiwan), 2 January. Retrieved 26 January 2019 from https:/english.president.gov.tw/News/ 5621.

Wang, Chris (2013) 'Political division must be resolved: Xi Jinping', Taipei Times, 7 October. Retrieved 8 September 2018 from www.taipeitimes.com/News/front/ archives/2013/10/07/2003573898/1.

Wang, Zheng (2014) Never Forget National Humiliation: Historical Memory in Chinese Politics and Foreign Relations, New York: Columbia University Press.

Weatherley, Robert and Zhang, Qiang (2017) History and National Legitimacy in Contemporary China: A Double Edged Sword, Basingstoke: Palgrave Macmillan.

$\mathrm{Xi}$, Jinping (2017) 'Full text of Xi Jinping's report at 19th CPC National Congress', Xinhua, 3 November. Retrieved 20 February 2019 from www.xinhuanet.com/english/ special/2017-11/03/c_136725942.htm.

Xi, Jinping (2019) 'Highlights of Xi's speech at gathering marking 4oth anniversary of Message to Compatriots in Taiwan', Xinhua, 2 January. Retrieved 20 February 2019 from www.xinhuanet.com/english/2019-01/02/c_137715300.htm.

Xiang Bo (ed) (2018) China Welcomes WHA's Decision Not to Include Taiwan-Related Proposal in Provisional Agenda, Press release, Xinhua, 22 May. Retrieved 2 September 2018 from www.xinhuanet.com/english/2018-05/22/c_137197985.htm. 